\title{
PENGEMBANGAN PARADIGMA BARU KEILMUAN DAN KELEMBAGAAN PENDIDIKAN NON FORMAL
}

\author{
Sodiq A. Kuntoro*
}

\begin{abstract}
According to the education law of Republic of Indonesia in 2003, non-formal education is implemented to facilitate the citizen to get education and it functions as substitution, supplement, and complement to formal education. The role of non-formal education is to contribute the implementation of lifelong education as a new approach to education. This new approach is different from the education under present systems that involve the attempt to integrate the different parts of education with the concern for the development of person in intellectual, emotional, social, and vocational aspects. The present non-formal education activities need to expand their activities to create opportunity of education wider and to cover incidental learning as a part of learning activities in society.
\end{abstract}

Keywords: non-formal education, lifelong education, incidental learning.

\section{PENDAHULUAN}

Dalam Undang-Undang (UU) Republik Indonesia No. 20 Tahun 2003 Tentang Sistem Pendidikan Nasional (Sisdiknas), telah dimuat peran penting Pendidikan Non Formal (PNF) dalam perluasan layanan pendidikan bagi warga masyarakat sehingga warga masyarakat yang tidak dapat mengikuti pendidikan formal ke jenjang lebih tinggi dapat memperoleh layanan pendidikan melalui program PNF. Pasal 26 ayat $1 \mathrm{UU}$ tersebut menyatakan: PNF diselenggarakan bagi warga masyarakat yang memerlukan layanan pendidikan yang berfungsi sebagai pengganti, penambah, dan atau pelengkap pendidikan formal dalam rangka mendukung pendidikan sepanjang hayat.

Pernyataan ini mengandung makna penting bahwa PNF mempunyai peran penting bagi perluasan layanan pendidikan bagi masyarakat, di samping layanan pendidikan yang diberikan oleh pendidikan formal. Kedua bentuk pendidikan itu bersifat saling melengkapi, menambah, dan menggantikan peranperan salah satu bentuk pendidikan yang kurang dapat memenuhi kebutuhan pendidikan warga masyarakat.

Di samping itu, pernyataan di atas juga mengandung makna peran PNF sebagai kegiatan pendidikan yang dapat mendukung terwujudnya aktivitas pendidikan sepanjang hayat. Permasalahannya adalah apakah aktivitas PNF yang sekarang ini dilaksanakan dapat mendukung terwujudnya pendidikan sepanjang hayat.

Tema tulisan ini memuat suatu analisis tentang realita pelaksanaan PNF, dan pemikiran ke depan pengembangan paradigma baru PNF agar dapat lebih berfungsi mendukung terwujudnya pendekatan pendidikan sepanjang hayat.

\section{PEMBAHASAN}

\section{Paradigma Baru Keilmuan PNF}

Paradigma baru keilmuan PNF sebenarnya sudah mulai muncul sejak sekitar 1970-an, di mana mulai dimunculkannya oleh para ahli konsep pendidikan sepanjang hayat. Kantor UNESCO di Paris pada tanggal 25 September-2 Oktober 1972 menyelenggarakan "Interdisciplinary Symposium on Lifelong Education" yang mengundang banyak ahli dan peserta dari

* Dosen Universitas Negeri Yogyakarta berbagai negara. Pada waktu itu di negara maju sudah sangat terasa kebutuhan akan pengembangan pendidikan dan pelatihan di industri untuk meningkatkan kualitas Sumber Daya Manusia (SDM) di mana pengetahuan, keterampilan, nilai, sikap, dan pertukaran dipandang memiliki peran penting dalam menghadapi ekonomi baru dan tantangan. Faktor manusia dipandang sebagai faktor utama bagi aktivitas ekonomi, persaingan, dan kemakmuran. Lulusan sekolah yang sudah bekerja semakin dituntut untuk 
meningkatkan pengetahuan dan keterampilannya agar tidak tertinggal dari perkembangan pengetahuan dan teknologi. Tempat kerja (industri) sangat memperhatikan kebutuhan pengembangan kualitas SDM-nya agar dapat mendukung kemajuan ekonomi, persaingan, dan kemakmuran. Program pendidikan dan pelatihan banyak dikembangkan di masyarakat, program pendidikan kelanjutan (continuing education) bagi para pemuda yang tamat sekolah untuk menyiapkan mereka masuk dunia kerja. Masyarakat dituntut untuk dapat memberikan layanan pendidikan yang lebih luas karena keberhasilan pendidikan sekolah mendorong kebutuhan akan mencari pengetahuan bagi semua orang di masyarakat semakin meningkat.

Di negara kita pada waktu itu tuntutan kebutuhan untuk mengembangkan dan mengimplementasikan konsep pendidikan sepanjang hayat belum begitu terasa karena kondisi kemajuan industri, teknologi, ekonomi, dan sosial belum terlalu menuntut untuk hal tersebut. Sekarang ini terjadi perubahan yang sangat cepat di kawasan Asia Tenggara karena kemajuan yang dicapai dalam pengembangan industri dan ekonomi serta kehidupan

Pendidikan sepanjang
hayat merupakan suatu
pendekatan pendidikan baru
yang berbeda dengan
pendidikan saat ini, di mana
peran-peran baru dan
fleksibilitas kelembagaan
dikembangkan agar dapat
menjangkau perluasan layanan
pendidikan.

yang harus dikembangkan bagi implementasi pendekatan baru pendidikan sepanjang hayat belum ada pembahasan. Pendidikan sepanjang hayat merupakan suatu pendekatan pendidikan baru yang berbeda dengan pendidikan saat ini, di mana peranperan baru dan fleksibilitas kelembagaan dikembangkan agar dapat menjangkau perluasan layanan pendidikan. Dalam pendekatan pendidikan sepanjang hayat semua aktivitas pendidikan dalam kotak-kotak yang terpisah, seperti kejuruan dan umum, formal dan informal, sekolah dan luar sekolah, serta kebudayaan dan pendidikan diupayakan untuk diintegrasikan dengan suatu pandangan yang bersifat organik bahwa semua aktivitas pendidikan dilakukan dalam kehidupan yang berguna bagi pengembangan manusia secara utuh dihargai dan tidak perlu dibedakan sebagai kegiatan pendidikan.

Dalam pendekatan pendidikan sepanjang hayat, kegiatan pendidikan atau belajar tidak lagi menekankan pada sekedar pemilikan (having) sejumlah stok ilmu pengetahuan yang diberikan oleh pemegang otoritas pengetahuan seperti guru di sekolah. Pendidikan lebih menekankan aktivitas belajar bagi pengembangan diri (being) baik yang dilakukan dalam bentuk sosial. Kebutuhan untuk mengembangkan dan mengimplementasikan konsep pendidikan sepanjang hayat di negara kita, sekarang ini sudah terasa sangat dibutuhkan untuk dilaksanakan. United Nations Educational, Scientific, and Cultural Organization (UNESCO) melalui konferensi yang diselenggarakan di Jomtien (Thailand) tahun 1990 mendeklarasikan program education for all (pendidikan bagi semua) sebagai strategi pengembangan pendidikan sepanjang hayat terutama di negara Asia-Pasifik. Visi pendidikan diperluas untuk membantu masyarakat. Pertama, untuk memperoleh kecakapan bagi kelangsungan hidup melalui pendidikan pra-sekolah, pendidikan dasar, dan program keaksaraan fungsional. Kedua, untuk memperoleh pengetahuan dan keterampilan bagi meningkatkan kualitas kehidupan, meningkatkan sikap, dan kebiasaan untuk belajar melalui program continuing education (pendidikan berkelanjutan).

Undang-undang Sisdiknas Republik Indonesia Tahun 2003 Pasal 26 menegaskan peran PNF bagi mendukung pelaksanaan pendidikan sepanjang hayat. Namun demikian, bagaimana peran itu harus dilakukan dengan konsep, keilmuan, dan strategi kelembagaan formal, nonformal atau informal dengan kurikulum yang dirancang oleh lembaga atau yang dirancang oleh dirinya sendiri secara self-education atau self-directing. Aktivitas belajar yang dilakukan secara terorganisir oleh diri sendiri dengan tujuan bagi pengembangan diri bahkan kegiatan belajar yang bersifat insidental yang terjadi dalam waktu singkat dilakukan dalam rentang waktu kehidupan individu perlu mendapatkan penghargaan sebagai bagian dari kegiatan pendidikan. Seperti ungkapan yang sekarang berkembang, menurut Okamoto (1994) hampir seluruh aktivitas dalam kehidupan dapat dipandang sebagai bagian dari belajar sepanjang hayat.

Hal yang penting dalam pendekatan pendidikan sepanjang hayat adalah adanya dalam diri individu dan masyarakat, suatu keinginan atau kemauan untuk terus menerus belajar, dan kemauan mengembangkan diri berkelanjutan (continuing self development). Persoalannya adalah sudah siapkah individu dan masyarakat dengan budaya belajar, yaitu sikap dan perilaku menyenangi dan menghargai aktivitas belajar bagi pengembangan dirinya. Apakah layanan pendidikan sekarang ini baik formal, nonformal, dan 
informal sudah dapat membentuk dalam diri individu dan masyarakat suatu nilai sikap, dan perilaku yang menyenangi kegiatan belajar.

Sebagaimana di depan telah disinggung bahwa program pendidikan bagi semua (education for all) sebagai suatu strategi untuk dapat mewujudkan pelaksanaan pendidikan sepanjang hayat. Dalam program pendidikan bagi semua (konferensi Jomtien) terdapat dua program perluasan layanan pendidikan. Pertama, perluasan layanan pendidikan bagi pendidikan pra sekolah (kelompok bermain dan TK), perluasan layanan pendidikan dasar, dan pendidikan keaksaraan fungsional. Dengan terjangkaunya semua anak dalam pendidikan pra sekolah, tercapainya penuntasan wajib belajar sembilan tahun bagi anak usia sekolah, dan penuntasan pendidikan keaksaraan fungsional bagi orang dewasa yang buta huruf diharapkan semua orang dapat dilengkapi dengan pengetahuan, keterampilan, sikap, dan nilai-nilai untuk dapat menjaga kelangsungan hidupnya. Program perluasan pendidikan tersebut di atas menjangkau semua orang diletakkan sebagai tujuan dasar membangun manusia agar dapat survival dalam hidupnya atau tidak mengalami kehancuran kehidupannya.

Kedua, diarahkan pada perluasan program continuing education (pendidikan berkelanjutan), dimaksudkan untuk agar supaya semua orang dapat meningkatkan kualitas kehidupannya dan meningkatkan sikap dan kebiasaan belajar. Mereka yang sudah menyelesaikan pendidikan dasar dan menyelesaikan program keaksaraan fungsional perlu memperoleh layanan pendidikan kelanjutan dengan tujuan agar mereka dapat meningkatkan kualitas hidupnya dan meningkatkan sikap dan nilai menyenangi kegiatan belajar. Di negara kita tampaknya sedang berusaha dengan sungguh-sungguh untuk mewujudkan program pendidikan bagi semua disebutkan di atas.

Program-program pendidikan untuk semua seperti di atas diuraikan adalah merupakan suatu strategi untuk mewujudkan pendidikan sepanjang hayat atau untuk mewujudkan terbentuknya masyarakat belajar sepanjang hayat (lifelong learning society). Persoalannya adalah mampukah program pendidikan pra sekolah, pendidikan dasar, dan pendidikan keaksaraan fungsional membangun sikap dan nilai menghargai serta menyenangi kegiatan belajar yang dituntut bagi terwujudnya masyarakat belajar sepanjang hayat. Terdapat kecenderungan pada pendidikan dasar (pendidikan sekolah) bahwa orientasi pendidikannya cenderung pada pemberian pengetahuan dari guru pada siswa. Sehingga siswa lebih cenderung diposisikan sebagai penerima pengetahuan secara pasif dan guru sebagai pemegang otoritas keilmuan cenderung bersifat dominan sebagai penentu pengetahuan yang diberikan.

Dalam kondisi seperti ini para siswa cenderung kurang memiliki pengalaman untuk dapat berpartisipasi dalam pencarian dan penemuan pengetahuan serta dengan demikian rasa ingin tahu intelektual siswa kurang berkembang. Lebih jauh sikap dan nilai-nilai menyenangi kegiatan belajar kurang dapat terbentuk dalam diri anak karena sikap dan nilai tersebut hanya dapat tumbuh dan berkembang apabila siswa memiliki pengalaman yang menyenangkan dalam berpartisipasi untuk pencarian dan penemuan pengetahuan. Implikasi pelaksanaan pendidikan sepanjang hayat bagi pendidikan dasar (persekolahan) adalah transformasi proses pembelajaran dari proses penyampaian pengetahuan oleh guru pada siswa menjadi proses mengembangkan sikap dan kebiasaan siswa belajar mencari dan menemukan pengetahuan. Begitu juga dalam diri siswa harus ditanamkan sikap dan nilai bahwa pengetahuan bukan hanya bersumber dari buku dan guru saja tetapi mereka memahami bahwa kehidupan alam dan manusia adalah sebagai sumber yang sebenarnya dari pengetahuan. Sehingga anak dituntut untuk lebih banyak belajar dari alam dan kehidupan manusia itu sendiri.

Begitu juga program keaksaraan fungsional yang sekarang ini dijadikan program luas secara nasional dalam rangka untuk membebaskan masyarakat dari kebutaan aksara (membaca dan menulis) dengan tujuan untuk mencerdaskan kehidupan masyarakat. Penduduk yang buta aksara secara umum mereka juga menderita lemahnya kemampuan kognitif dalam memahami permasalahan kehidupan sehingga mereka kurang memiliki kemampuan dalam memecahkan masalah tersebut. Oleh karena itu, program pendidikan keaksaraan dalam pelaksanaannya harus dikaitkan dengan peningkatan kemampuan kognitif maupun keterampilan memecahkan permasalahan kehidupan. Pendidikan keaksaraan tidak dapat dilihat secara sempit sekedar mengajar membaca dan menulis yang tidak terkait dengan tujuan mencerdaskan kehidupan. Apabila pendidikan keaksaraan diarahkan pada perbaikan kehidupan yang dihadapi warga belajar maka dalam proses pembelajaran keaksaraan fungsional perlu dikembangkan tumbuhnya kesadaran bahwa situasi kehidupan yang mereka hadapi dapat dilakukan perbaikan.

Untuk dapat membentuk sikap dan nilai menyenangi dan menghargai kegiatan belajar maka proses pembelajaran pendidikan keaksaraan fungsional seharusnya menggunakan pendekatan pembelajaran partisipatoris dan andragogis. Permasalahannya adalah dapatkah mereka para pekerja di lapangan dalam 
pelaksanaan kegiatan pendidikan keaksaraan fungsional menggunakan pendekatan tersebut.

Seperti di depan dikatakan dalam UndangUndang Sisdiknas Republik Indonesia Tahun 2003 Pasal 26 menyatakan peran PNF bagi mendukung pelaksanaan pendidikan sepanjang hayat. Persoalannya apakah PNF yang sekarang ini dikembangkan dapat mendukung pelaksanaan pendidikan sepanjang hayat? Sesuai dengan simposium internasional pendidikan sepanjang hayat di Paris (1972) yang telah disinggung di depan disepakati bahwa pendidikan sepanjang hayat memiliki dua dimensi, yaitu dimensi vertikal dan horizontal. Dimensi vertikal mengandung pengertian bahwa kegiatan pendidikan berjalan sepanjang hayat (dari lahir sampai meninggal) sedangkan dimensi horizontal mengandung pengertian bahwa kegiatan pendidikan mencakup keseluruhan aktivitas kehidupan manusia mulai dari aktivitas mengisi waktu luang sampai peran warga negara pada proses politik.

Pasal 26 ayat 3 Undang-undang Sisdiknas menyebutkan pendidikan nonfromal meliputi pendidikan kecakapan hidup, pendidikan anak usia dini, pendidikan kepemudaan, pendidikan pemberdayaan perempuan, pendidikan keaksaraan, pendidikan keterampilan dan pelatihan kerja, pendidikan kesetaraan, serta pendidikan lain yang ditujukan untuk mengembangkan kemampuan peserta didik.

Apabila program pendidikan nonfromal di atas dijadikan program untuk menyiapkan pelaksanaan pendidikan sepanjang hayat yang memiliki dimensi vertikal dan horizontal yang sangat luas sebagaimana telah dijelaskan maka program-program tersebut dirasakan masih sangat kurang. Dibutuhkan perluasan program PNF yang sekarang ada, dengan memasukkan program PNF dan informal yang terjadi di masyarakat, atau program pendidikan yang memungkinkan terjadinya kegiatan self education atau self directed learning dan incidental learning.

\section{Agenda dan Strategi Pengembangan Layanan PNF}

Sekarang ini program layanan PNF yang banyak dilakukan adalah program kecakapan hidup yang dilakukan oleh lembaga kursus kelompok belajar, dan pusat kegiatan belajar masyarakat (PKBM) yang didirikan secara sukarela oleh masyarakat. Sementara program pendidikan anak usia dini sebagai program pendidikan bagi anak-anak usia 2 - 4 tahun mulai banyak berkembang di masyarakat yang umumnya dilakukan oleh lembaga kemasyarakatan, dengan tujuan untuk membantu tumbuh kembang anak-anak. Pendidikan kepemudaan dilakukan dalam bentuk yang beraneka ragam seperti pendidikan kepramukaan, program pendidikan karang taruna, program pendidikan olahraga dan seni bagi pemuda. Program-program tersebut tidak terlalu ketat apakah dilakukan oleh departemen pendidikan nasional atau juga dilakukan oleh departemen lain. Program pendidikan pemberdayaan perempuan justru lebih banyak dilakukan olah lembaga swadaya masyarakat dan kementerian pemberdayaan perempuan, serta organisasi wanita yang berdiri dengan sponsor pemerintah maupun organisasi sosial masyarakat yang independen.

Program pendidikan keaksaraan yang sekarang dijadikan program luas secara nasional dalam rangka untuk membebaskan masyarakat dari kebutaan aksara (membaca dan menulis) dan mencerdaskan kehidupan masyarakat. Penduduk yang buta aksara secara umum mereka juga menderita dalam kemampuan kognitif untuk memahami permasalahan kehidupan sehingga mereka kurang memiliki kemampuan untuk memecahkan masalah tersebut. Olah karena itu, program pendidikan keaksaraan dalam pelaksanaannya harus dikaitkan dengan peningkatan kemampuan kognitif maupun keterampilan memecahkan permasalahan kehidupan. Pendidikan keaksaraan tidak dapat dilihat secara sempit sekedar mengajar membaca dan menulis tetapi harus dipandang secara luas untuk tujuan mencerdaskan kehidupan masyarakat. Pelaksanaan program pendidikan keaksaraan ini melibatkan organisasi sosial kemasyarakatan [seperti organisasi Aisyiah/organisasi wanita Muhammadiyah, organisasi wanita Nahdlatul Ulama (NU), dan organisasi PKK] dan juga kegiatan perguruan tinggi melalui kegiatan KKN. Pemerintah daerah memiliki peran besar dalam pelaksanaan pendidikan keaksaraan ini karena data dari pemerintah daerah tentang jumlah penduduk yang menjadi sasaran merupakan faktor yang pertama sangat penting. Komitmen pemerintah daerah dalam pemberantasan buta aksara memegang peran kunci untuk pencapaian keberhasilan program ini karena gerakan pemberantasan buta aksara membutuhkan partisipasi warga masyarakat yang dapat digerakkan oleh pemerintah tingkat daerah dan desa.

Program pendidikan keterampilan dan pelatihan banyak berkembang dalam masyarakat, dilaksanakan oleh lembaga atau organisasi pemerintah maupun masyarakat. Lembaga kursus yang didirikan oleh masyarakat melaksanakan bermacam-macam layanan pendidikan terutama bagi pemuda lulusan sekolah yang tidak melanjutkan pendidikan ke jenjang lebih tinggi. Pendidikan yang dilakukan oleh lembaga kursus di masyarakat ini dapat dimasukkan sebagai "continuing 
education" yang memberikan pengetahuan dan keterampilan praktis bagi peserta didik. Kursus keterampilan seperti kursus komputer, menjahit, montir mobil, $A C$, kulkas, kursus tata rias, bahasa asing, dan sekretaris banyak diikuti oleh lulusan sekolah dan berfungsi sebagai penambah atau pelengkap pendidikan sekolah yang bersifat fungsional bagi memenuhi kebutuhan pasar kerja. Di samping lembaga kursus yang didirikan oleh masyarakat, Balai Latihan Kerja (BLK) di bawah departemen tenaga kerja memberi layanan pendidikan dan pelatihan bagi pemuda lulusan sekolah yang dipersiapkan untuk segera memasuki dunia kerja. BLK didirikan oleh pemerintah memberi layanan pelatihan secara terbuka bagi semua warga masyarakat yang membutuhkan untuk menyiapkan diri memasuki dunia kerja.

Pendidikan keteram-pilan dan kepelatihan juga berkembang di lembaga kerja baik di kantor pemerintah maupun industri dan dunia usaha. Kegiatan pendidikan dan latihan diberikan bagi para pekerjanya dalam upaya meningkatkan pengetahuan, keterampilan, sikap, dan nilai-nilai agar dapat mengikuti perkembangan teknologi dan kemajuan ekonomi. Kepelatihan ini bersifat inservice training yang diharapkan dapat meningkatkan kemampuan SDM bagi organisasi kerja untuk menghadapi persaingan dalam dunia usaha. Program pendidikan dan pelatihan secara umum lebih berorientasi pada peningkatan SDM dalam upaya untuk pencapaian kemajuan ekonomi.

Program pendidikan kesetaraan merupakan bagian dari layanan PNF yang bersifat khas, yaitu sebagai fungsi pengganti pendidikan formal. Program ini ditujukan bagi anak-anak atau pemuda yang tidak dapat memasuki atau menyelesaikan sekolah dasar dengan diberikan Program Paket A kesetaraan SD, anak-anak atau pemuda yang tidak dapat memasuki dan menyelesaikan sekolah menengah pertama diberikan Program Paket B kesetaraan SMP, dan pemuda yang tidak dapat memasuki dan menyelesaikan sekolah menengah atas diberikan Program Paket $C$ kesetaraan SMA. Program pendidikan kesetaraan, walaupun dilakukan dalam jalur PNF tetapi memiliki pengakuan tentang ijazahnya setara atau sama dengan jenjang-jenjang pendidikan formal. Program pendidikan ini banyak berkembang di masyarakat untuk menampung anak dan pemuda yang putus sekolah dan mereka masih memiliki keinginan untuk melanjutkan studinya atau memasuki dunia kerja.

Berdasarkan uraian di atas tampak bahwa program-program PNF sebagaimana disebutkan dalam Undang-Undang Sisdiknas pasal 26 ayat 3 memiliki tujuan dan kegiatan belajar yang beraneka ragam dan dilakukan oleh banyak lembaga tidak terbatas dari departemen pendidikan nasional saja. Departemen lain yang terlibat dalam layanan PNF antara lain departemen tenaga kerja, pemuda dan olah raga, dan kementerian pemberdayaan perempuan. Di sini tampak adanya kompleksitas pengembangan layanan PNF karena di samping variasi programnya dengan sasaran peserta didik yang berbeda-beda tetapi juga satuan pendidikan yang menyelenggarakan kegiatan PNF berada dalam departemen atau organisasi sosial yang beraneka ragam.

Persoalan yang muncul adalah pengorganisasian layanan PNF di masyarakat agar program-program tersebut dapat terkoordinasi terkait satu dengan yang lain dalam rangka upaya untuk dapat mendukung pendidikan sepanjang hayat. Dalam pelaksanaan pendidikan sepanjang hayat dibutuhkan suatu perubahan sikap, nilai-nilai, dan perilaku warga masyarakat dari hanya sekedar mengikuti kegiatan belajar yang diarahkan oleh orang lain atau lembaga penyelenggara kegiatan pendidikan, berkembang menjadi perilaku yang diarahkan oleh diri sendiri sebagai perwujudan dari kebutuhan belajar dan rasa ingin tahu intelektual atau perolehan keterampilan untuk mengembangkan kehidupan. Sebagaimana telah disampaikan sebelumnya, tujuan pendidikan sepanjang hayat bukan sekedar untuk peningkatan pengetahuan dan keterampilan dalam rangka perbaikan keadaan ekonomi peserta didik atau warga masyarakat tetapi lebih luas dari itu, yakni untuk pencapaian kualitas kehidupan yang lebih baik.

Tantangan yang dihadapi oleh penyelenggara layanan PNF adalah kemampuan pengembangan program pendidikan yang sesuai dengan kebutuhan peserta didik dengan kondisi sosial-budaya spesifik yang dimilikinya. Program pendidikan yang menyajikan kegiatan belajar tidak sesuai dengan kebutuhan peserta didik tentu kurang dapat menumbuhkan minat atau keinginan belajar peserta didiknya sehingga mungkin mereka mengikuti kegiatan belajar karena sekedar adanya paksaan dari luar. Sebaliknya, apabila program belajar menyajikan kegiatan belajar yang sesuai dengan kebutuhan belajar peserta didiknya maka akan dapat mengembangkan minat dan keinginan belajar peserta didiknya. Sesuai dengan teori andragogi (Knowles, 1979) menyampaikan bahwa orang dewasa tertarik belajar apabila program belajar itu memenuhi kebutuhan dan minatnya. Minat dan kebutuhan belajar peserta didik adalah merupakan titik awal dari aktivitas pengorganisasian belajar orang dewasa. Hal ini mengisyaratkan bahwa dalam pengembangan program PNF maka kebutuhan dan minat peserta didik harus dijadikan dasar bagi pengembangan kurikulumnya. 
Di samping itu, proses pembelajaran dalam PNF membutuhkan pendidikan yang berbeda dengan caracara yang umumnya dilakukan dalam pendidikan formal. Peserta didik PNF umumnya adalah pemuda dan orang dewasa yang sudah terlibat dalam kegiatan bekerja atau pengembangan peran dalam pekerjaannya mereka membutuhkan model dan gaya belajar yang berbeda dengan anak-anak di sekolah. Pendekatan pembelajaran yang menyampaikan pengetahuan abstrak yang tidak terkait dengan pengalaman kehidupan untuk memahami permasalahan konkret kurang menarik bagi peserta didik dewasa. Teori andragogi (Knowles, 1979) menjelaskan bahwa orientasi belajar orang dewasa adalah berpusat pada kehidupan, bukan pada mata pelajaran (pengetahuan abstrak) yang terpisah dengan kehidupan. Orang dewasa yang sudah memiliki kekayaan pengetahuan, mereka lebih senang apabila cara belajar yang diterapkan dalam proses pembelajaran menggunakan dan menghargai pengalaman mereka. Oleh karenanya metode pembelajaran yang tepat bagi orang dewasa adalah analisis pengalaman.

Pengembangan model program dan model pembelajaran bagi peserta didik dalam PNF, masih kurang dipahami oleh para penyelenggara kursus, kepelatihan, atau para tutor sehingga mereka kurang dapat menciptakan program belajar yang sesuai dengan kebutuhan spesifik kelompok sosial-budaya peserta didik dan model pembelajaran yang dapat membangkitkan minat dan rasa senang untuk belajar. Apabila para penyelenggara kursus, kepelatihan atau para tutor (guru) tidak dapat menciptakan program dan iklim belajar yang sesuai dan menyenangkan maka tugas atau peran PNF untuk membangun perubahan sikap, nilai, dan perilaku peserta didik menghargai belajar,dalam rangka mendukung pelaksanaan pendidikan sepanjang hayat dapat dikatakan kurang berhasil.

Dalam layanan program PNF dalam rangka mendukung pelaksanaan pendidikan sepanjang hayat dibutuhkan suatu model pendidikan yang bersifat transformational learning (Mezirow dalam Merriam, 2001), yaitu kegiatan belajar yang dapat menghasilkan perubahan kerangka berpikir (peta kognitif) dan perubahan kesadaran (afektif) dari peserta didik sehingga kegiatan belajar berkembang menjadi tindakan (action) untuk mencapai kehidupan baru yang lebih baik. PNF seharusnya tidak menggunakan model belajar yang cenderung sekedar mengumpulkan pengetahuan luar diri (out there-knowledge) tetapi membangun pengetahuan melalui aktivitas interpretasi dan reinterpretasi melalui pengalaman-pengalaman baru sehingga terbentuk pengetahuan dalam diri (in hereknowledge) yang dapat dijadikan dasar untuk tindakan melakukan perubahan kehidupan atau action knowledge (Barnes, 1977).

Freire (1977) yang bekerja dalam program pendidikan keaksaraan bagi penduduk miskin yang buta huruf mendorong dirinya untuk menyadari bahwa model pendidikan gaya bank (banking method) yang menekankan mendengarkan secara pasif dan menerima fakta atau informasi dari guru menjadikan siswa tidak berdaya membangun interpretasinya. PNF bagi pemuda dan orang dewasa yang terbelenggu dalam situasi kehidupan yang mereka hadapi harus mengarahkan pada fungsi pemberdayaan. Dengan kata lain programprogram PNF harus dapat berfungsi untuk mencerdaskan kehidupan masyarakat, yaitu kemampuan peserta didik menginterpretasi informasi, memahami permasalahan kehidupan, dan menemukan cara pemecahannya.

Penduduk yang menderita buta aksara secara umum mereka juga kurang memiliki kemampuan untuk memahami permasalahan kehidupan yang mereka hadapi, seperti kondisi kemiskinan, penyakit, dan pengangguran sehingga mereka kurang memiliki kemampuan untuk memecahkannya. Program pendidikan keaksaraan bagi tujuan untuk mencerdaskan kehidupan masyarakat maka dibutuhkan suatu metode pendidikan keaksaraan yang bersifat transformative-learning sehingga para peserta didik bukan sekedar belajar membaca-menulis secara mekanis yang terlepas dari kemampuan memahami permasalahan kehidupan. Program pendidikan keaksaraan di samping mengajarkan kemampuan membaca dan menulis, juga menjadi kegiatan pemberdayaan peserta didik untuk memahami permasalahan kehidupan yang mereka hadapi dan mendorong kemauan mereka untuk melakukan tindakan mengubah situasi kehidupan menjadi lebih baik.

Program-program layanan PNF dalam rangka mendukung pelaksanaan pendidikan sepanjang hayat membutuhkan perluasan layanan program PNF yang diselenggarakan di masyarakat. Selama ini program PNF yang diselenggarakan bagi masyarakat masih menekankan pada program terstruktur, seperti program kursus dan kepelatihan tetapi program PNF-informal yang dapat mendorong aktivitas belajar mandiri (selfeducation) atau self directed learning dan kegiatan belajar insidental (incidental learning) kurang dirancang dan dikembangkan dengan baik. Kegiatan lembaga kebudayaan dan keagamaan, seperti aktivitas museum, festival kebudayaan, keagamaan, seni, dan rekreasi 
atau mengisi waktu luang yang memungkinkan terjadinya incidental learning masih belum dirancang dengan baik sebagai bagian dari program pendidikan sepanjang hayat. Apabila kita mengikuti konsep tiga pusat pendidikan, yaitu keluarga, sekolah, dan masyarakat maka dalam pendidikan masyarakat mencakup pengertian aktivitas pendidikan yang diperoleh dalam kehidupan masyarakat yang dapat berupa program pendidikan terstruktur, seperti kursus dan pelatihan tetapi juga program pendidikan dalam peristiwa kebudayaan, seni atau agama yang memungkinkan individu belajar secara mandiri dan belajar secara insidental. Sejalan dengan konsep belajar dalam sistem pendidikan sepanjang hayat, seperti telah disampaikan sebelumnya bahwa semua aktivitas dalam keseluruhan kehidupan dapat dipandang sebagai bagian dari belajar sepanjang hayat (Okamoto, 1994).

Agenda layanan PNF dalam rangka mendukung pelaksanaan pendidikan sepanjang hayat tidak cukup hanya sekedar terpusat pada kegiatan pendidikan yang terstruktur, seperti pendidikan kecakapan hidup, pendidikan anak usia dini, pendidikan kepemudaan, pendidikan pemberdayaan perempuan, pendidikan keaksaraan, pendidikan keterampilan dan pelatihan kerja, dan pendidikan kesetaraan; sebagaimana keadaan sekarang yang dilakukan. Pendidikan sepanjang hayat adalah pendidikan baru yang memberikan kesempatan semua warga masyarakat terlibat melakukan kegiatan belajar baik melalui kegiatan yang dilaksanakan oleh agen pembelajaran tetapi dapat juga melalui self-education dan incidental learning yang diarahkan oleh dirinya sendiri. Oleh karenanya, layanan PNF seharusnya juga memberikan layanan untuk berkembangnya Self-education dan incidental learning. Peristiwa kebudayaan, keagamaan, rekreasi, olahraga, kegiatan museum, taman bacaan, festival, dan pameran adalah menjadi sumber belajar penting bagi self education dan incidental learning sehingga perlu dirancang dan dikembangkan untuk tujuan pendidikan atau belajar sehingga dapat terwujud setiap orang memperoleh kesempatan belajar yang dapat mendorong terciptanya masyarakat belajar sepanjang hayat (life-long learning society).

\section{Pengembangan Kelembagaan}

Di masa depan, perluasan layanan PNF yang tidak hanya terbatas pada layanan pendidikan yang terstruktur yang dilakukan oleh satuan pendidikan, tetapi juga mencakup layanan pendidikan bagi aktivitas self-education dan incidental learning. Apabila demikian maka layanan PNF akan menjadi luas lagi yang mungkin mencakup seluruh lembaga dalam masyarakat baik bersifat pemerintah atau nonpemerintah akan berfungsi sebagai agen layanan pembelajaran. Lembaga-lembaga di masyarakat yang sekarang dipandang sebagai lembaga yang tidak melayani aktivitas pendidikan, seperti lembaga perdagangan (pasar, toko, dan supermarket), lembaga rekreasi (kebun binatang, museum, dan kolam renang), serta lembaga pengobatan kesehatan (rumah sakit, poliklinik, dan puskesmas) pada waktu yang akan datang lembaga tersebut berperan juga sebagai agen layanan pembelajaran dalam rangka terwujudnya pendidikan sepanjang hayat.

Program layanan PNF yang sekarang ini berjalan tentu saja kurang dapat mendukung terwujudnya pelaksanaan pendidikan sepanjang hayat maka dibutuhkan strategi pengembangan layanan PNF yang baru. Strategi baru ini termasuk pengembangan kelembagaan, peraturan yang mendukung, organisasi pendidikan sepanjang hayat, bermacam-macam fasilitator kegiatan belajar di masyarakat, koordinasi, dan promosi.

Penjelasan strategi baru tersebut dijelaskan sebagai berikut.

1. Pengembangan kelembagaan

Untuk dapat melaksanakan sistem pendidikan sepanjang hayat dibutuhkan kelembagaan baru atau lembaga yang sudah ada sekarang ini ditransformasi untuk dapat melakukan tugas-tugas yang lebih luas. Oleh karena pelaksanaan pendidikan sepanjang hayat membutuhkan rancangan yang melibatkan banyak departemen dan lembaga nonpemerintah baik lembaga pendidikan dan lembaga yang selama ini tidak dianggap sebagai lembaga pendidikan.

Direktorat Jenderal PNF dan Informal (Ditjen PNFI) selama ini cenderung bekerja secara sektoral mungkin mengalami kesulitan untuk mendorong agar 
dapat bekerja lintas sektor yang melibatkan semua departemen dan lembaga dalam masyarakat untuk berperan dalam layanan pendidikan atau belajar. Oleh karenanya Ditjen ini harus dikembangkan perannya lebih luas untuk melakukan koordinasi program layanan pendidikan dari bermacam departemen dan masyarakat. Atau mungkin dibutuhkan lembaga baru seperti "Biro Pendidikan Sepanjang Hayat" yang bekerja memikirkan kebijakan, perencanaan, dan koordinasi pelaksanaan sistem pendidikan sepanjang hayat. Dengan adanya lembaga yang bertanggung jawab terhadap pelaksanaan sistem pendidikan sepanjang hayat maka diharapkan akan dapat mendorong adanya kebijakan yang jelas, perencanaan program, dan koordinasi pelaksanaannya.

\section{Peraturan yang mendukung}

Agar semua departemen dan lembaga yang selama ini dipandang tidak melakukan peran layanan pendidikan dapat terlibat dalam peran sebagai agen layanan pembelajaran maka dibutuhkan sebuah peraturan yang mendukung. Baik di tingkat pusat maupun di daerah dibutuhkan peraturan yang mendorong dalam rangka pelaksanaan pendidikan sepanjang hayat, semua departemen dan lembaga di masyarakat dalam aktivitas kerjanya memberikan partisipasinya untuk layanan pendidikan atau belajar. Sebagaimana telah disampaikan di atas bahwa lambaga ekonomi (pasar, rumah makan, toko, supermarket, dan bank), lembaga kesehatan (rumah sakit, poliklinik, dan puskesmas), serta lembaga rekreasi (kebun binatang, perhotelan, kolam renang, dan museum) dengan peraturan yang ditetapkan dalam rangka mendukung pendidikan sepanjang hayat dapat didorong untuk berpartisipasi melakukan layanan pendidikan atau belajar bagi masyarakat.

\section{Dewan pendidikan sepanjang hayat}

Di tingkat pusat dan di daerah sangat dibutuhkan suatu dewan yang bekerja untuk membuat kebijakan dan mengorganisir pelaksanaan sistem pendidikan sepanjang hayat. Mungkin saja tidak harus berbentuk lembaga baru tetapi dapat juga lembaga yang sudah ada seperti dewan pendidikan nasional (di pusat) dan dewan pendidikan daerah (di daerah) diberikan tugas baru untuk melakukan kajian dan pembuatan kebijakan tentang pelaksanaan pendidikan sepanjang hayat pada tingkat pusat atau tingkat daerah.

4. Bermacam-macam fasilitas belajar di masyarakat

Dalam rangka melaksanakan pendidikan sepanjang hayat maka fasilitas layanan belajar di masyarakat perlu diperluas sehingga memberi kemudahan setiap warga negara untuk memperoleh kesempatan belajar, baik melalui kegiatan terstruktur oleh lembaga atau dilakukan sendiri (self directed learning) maupun incidental learning yang terjadi dalam waktu singkat (mungkin tidak dirancang sejak awal). Di samping program PNF yang sekarang ini dilaksanakan, yaitu (1) pendidikan kecakapan hidup, (2) pendididkan anak usia dini, (3) pendidikan kepemudaan, (4) pendidikan pemberdayaan perempuan, (5) pendidikan keaksaraan, (6) pendidikan keterampilan dan pelatihan kerja, dan (7) pendidikan kesetaraan maka masih diperlukan adanya perluasan layanan pendidikan yang ada di masyarakat.

Fasilitas belajar di masyarakat, seperti taman bacaan masyarakat, Pusat Kegiatan Belajar Masyarakat (PKBM), taman pintar masyarakat, museum daerah, pusat kebudayaan, taman bermain anak-anak, taman olah raga, kebun binatang, dan peristiwa kebudayaan serta keagamaan, semuanya dibutuhkan bagi fasilitas belajar yang mendukung pelaksanaan sistem pendidikan sepanjang hayat.

\section{Koordinasi dan promosi}

Agar pelaksanaan pendidikan sepanjang hayat dapat terkoordinasi dengan baik maka dibutuhkan sistem kegiatan koordinasi dan promosi. Koordinasi dimaksudkan adalah aktivitas mengkoordinasikan aktivitas-aktivitas yang dilakukan oleh bermacammacam departemen dan lembaga dapat disinkronkan dalam tujuan yang sama.

Adapun promosi adalah kegiatan untuk terus menerus mendorong màsyarakat mengikuti sistem pendidikan sepanjang hayat dan ikut terlibat dalam gerakan pendidikan sepanjang hayat.

\section{KESIMPULAN}

PNF sebagai layanan pendidikan yang diberikan bagi warga masyarakat luas, memiliki arti penting dalam rangka mendukung pendidikan sepanjang hayat. Namun demikian, realita pelaksanaan PNF sekarang masih terpusat pada kegiatan pendidikan yang terstruktur seperti program pendidikan kecakapan hidup, pendidikan anak usia dini, pendidikan kepemudaan, pendidikan pemberdayaan perempuan, pendidikan keaksaraan, pendidikan keterampilan dan pelatihan kerja, serta pendidikan kesetaraan program 
PNFI yang dapat mendorong aktivitas belajar mandiri (self-education atau self directed learning) dan kegiatan belajar insidental (incidental learning) kurang dirancang dan dikembangkan dengan baik. Kegiatan lembaga kebudayaan dan keagamaan, seperti aktivitas museum, festival kebudayaan, keagamaan, seni, dan rekreasi yang memungkinkan terjadinya incidental learning masih belum dirancang dengan baik sebagai bagian dari program pendidikan sepanjang hayat.

Pendidikan sepanjang hayat sebagai pendekatan pendidikan baru yang memberi kesempatan semua warga masyarakat terlibat melakukan kegiatan belajar baik melalui kegiatan yang dilaksanakan terstruktur maupun melalui self-education atau incidental learning. Pengembangan kegiatan PNF tidak cukup hanya melalui layanan pendidikan terstruktur yang dilakukan oleh satuan pendidikan yang selama ini dikenal atau diakui. Lembaga-lembaga di masyarakat yang selama ini dipandang tidak melayani aktivitas pendidikan seperti lembaga perdagangan (toko dan pasar), lembaga rekreasi (kebun binatang dan kolam renang), dan lembaga pengobatan (rumah sakit dan poliklinik) pada waktu yang akan datang akan berperan sebagai agen layanan belajar dalam rangka terwujudnya masyarakat belajar sepanjang hayat.

Pelaksanaan sistem pendidikan sepanjang hayat membutuhkan rancangan yang melibatkan banyak departemen dan lembaga nonpemerintah baik lembaga pendidikan maupun lembaga yang selama ini tidak dianggap sebagai lembaga pendidikan. Oleh karenanya dibutuhkan koordinasi lintas sektoral yang memungkinkan melakukan kebijakan yang jelas, perencanaan program, dan koordinasi pelaksanaan pendidikan.

\section{DAFTAR PUSTAKA}

Barnes, D. (1977). From communication to curriculum. Auckland, N.Z: Penguin books, Ltd.

Freire, P. (1977). Pedagogy of the oppressed. Auckland, N.Z: Penguin books, Ltd.

Knowles, M. (1979). The adult learner: A neglected species. Houston: Gulf publishing company.

Merriam, S.B. (2001). The new update an adult learning theory. San Francisco: Jossey-Bass.

Okamoto, K. (1994). Lifelong learning movement in Japan, strategy, practices, and challenges.
Ministry of education, science, and culture.

UNESCO House. (1973). Interdisciplinary symposium on lifelong education. Paris.

UNESCO Principal Regional Office for Asia and The Pasific. (1993). Appeal training material for continuing education personnel. Bangkok.

(2003). Undang-Undang Republik Indonesia Nomor 20 Tahun 2003 Tentang Sistem Pendidikan Nasional. 